\section{Lege og samfunn for hundre år siden}

Bjorvatn $\emptyset$, red.

Gamledoktoren

Av og om dr. Stian Erichsen 1867-1953.

142 s, ill. Tvedestrand: Bokbyen forlag, 2009

Pris NOK 328

ISBN 978-82-92920-10-7

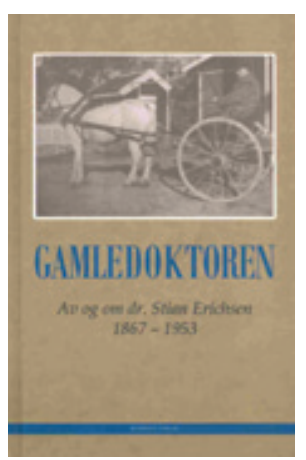

Det blir ofte fortalt om den gamle, gode legen som levde i mindre samfunn, alltid var tilgjengelig, og som etter hvert ble en institusjon. Under begrepet Gamledoktoren har vi med årene fătt en rekke bøker og artikler om denne typen lege. Det var den gang det var mer personlig ansvar og i mindre grad et helsevesen med systemansvar for folks helse. I siste halvdel av 1800-tallet gikk en hoveddel av legens arbeidstid med til å komme ut til pasientene, og det var en selvpålagt plikt.

Bokbyen forlag i Tvedestrand har gitt ut livserindringene til en av disse hederskronte gamledoktorene: distriktslege Stian Erichsen (1867-1953), som virket i over 30 år i Tvedestrand og siden noen år i Bærum. Erichsen skrev ned memoarene sine i årene 1949-51, da han var over 80 år. Øyvind Bjorvatn har redigert manuskriptet og laget en fyldig innledning med en minibiografi, slik at det ikke bare er en memoarbok, men også en minnebok om Stian Erichsen og hans samtid. En rekke småhistorier og anekdotisk stoff som har gått på folkemunne $i$ egnen blir fortalt $i$ et etterord til forfatterens egen tekst.

Da Erichsen begynte i praksis, benyttet legene hest med karjol eller slede og delvis båt for å komme rundt til pasientene. Først tidlig på 1900-tallet fikk han sin første automobil. Det var en blandet fornøyelse, men etter hvert ble det klart at kjøretøyet som gikk ved egen hjelp, hadde sine fordeler. Erichsen forteller løst og fast om praksisen sin, om opplevelser med pasienter, og også om samfunnsforhold, hva han så og opplevde. Han var en skarp iakttaker og gir et interessant tidsbilde av Tvedestrand og omgivelsene.

Dette er ikke noe stort litterært produkt, men like fullt koselig og sjarmerende lesing som supplerer bildet vårt av det å drive legepraksis for 100 år siden. Han forteller mye om lokalmiljøet og omtaler et stort persongalleri. Boken vil nok ha størst interesse for dem som har tilknytning til Sørlandet og spesielt Tvedestrand, men leger og annet helsepersonell med interesse for helsehistorie vil også ha glede av den.

Boken viser hvor viktig del av lokalsamfunnene de gamle legene har vært. I tillegg gir disse memoarene et sjarmerende bilde av folkeliv og helsestell. Når doktor Erichsen skulle i sykebesøk og isen hadde lagt seg på fjorden, kjørte han gjerne over isen i stedet for langs kronglete og svingete veier. På forhånd hektet han fordøren av, slik at han var klar til å hoppe ut om bilen skulle gå til bunns. Om disse legene hadde begrensede terapeutiske muligheter i praksisen, så var de i alle fall ikke skvetne!

\section{Ole Didrik Lærum}

Gades institutt

Haukeland universitetssykehus

\section{Apotekfarmasøytenes historie}

Hamran 0.

Den fortrinlige kundskab og dygtighed

Farmasøytenes historie i Norge 1858-2008.

311 s, ill. Oslo: Forlaget Press, 2008

Pris NOK 400

ISBN 978-827547-308-8

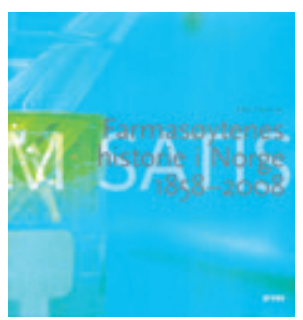

Da Norges Farmaceutiske Forening (NFF) feiret sitt 100-årsjubileum i 1958, ble det utgitt en jubileumsbok med enkeltartikler skrevet av norske farmasøyter (1). Til 150-årsjubileet hyret foreningen inn en profesjonell historiker. Olav Hamran leder Nasjonalt medisinsk museum ved Norsk Teknisk Museum og er også engasjert i andre historieprosjekter knyttet til norsk farmasi.

Hamrans profesjonelle grep viser seg bl.a. ved at boken i tillegg til en litteraturliste også byr på mange noter. Innholdsfortegnelsen er omfattende. Mens jubileumsskriftet fra 1958 har en beretning om NFFs historie pluss en rekke andre artikler fra forskjellige områder innen farmasien, er Hamrans bok en sammenhengende fremstilling. Men mens 1958-boken favner langt videre enn foreningens historie, er 2008-boken utstyrt med en altfor omfattende og ambisiøs undertittel: Hamran skriver ikke farmasøytenes historie i Norge. Hans fremstilling tar bare for seg NFF og de sakene foreningen har vært involvert i. Slik sett får forfatteren tydelig frem at apotek og apotekfarmasi har vært foreningens dominerende virkeområde. Dette vises ekstra godt for eksempel når han skriver: «Profilen som en forening for apotekansatte farmasøyter, ble tydeligere.» Farmasøyter i industri, forskning og undervisning har en marginal plass i boken, slik de har hatt i foreningens liv og virke. Mer påfallende er det kanskje at Hamran heller ikke ofrer sykehusfarmasien stor oppmerksomhet.

Boken innledes med en god beskrivelse av bakgrunn og utvikling innen norsk farmasi frem til opprettelsen av Den Pharmaceutiske Forening i 1858, og avsluttes med de radikale endringene apotekvesenet gjennomgikk etter en lovendring i 2001. Hamran vektlegger hvordan farmasøytene i dette tidsrommet gikk fra å være en håndverkspreget gruppe som lenge var sterkt uønsket på universitetet, til å bli en kategori som det samme universitetet nødig ville gi slipp på noen tiår senere - lenge før farmasi var blitt et eget studium. Farmasøytene beskrives som kvalitetsbevisste, men etter at økonomene har endret apotekbransjen, krever samfunnet at kvalitetsorienteringen skal være styrt av økonomiske forhold mer enn av farmasifaglige synspunkter.

Boken har mange helsides fotografier, noen gamle, de fleste nye. Det er imidlertid knapt at de kan kalles illustrasjoner i egentlig forstand, idet det ikke er noen sammenheng mellom tekst og bilde. Til å løse litt opp i en bok som ellers preges av mye tett skrift, fungerer det bra. Mange lesere vil likevel sikkert savne en mer tradisjonell layout der bildematerialet brukes til å utdype teksten.

\section{Kjell-Erik Andersen}

Vinterbro

\section{Litteratur}

1. Johannessen I, red. Jubileumsskrift. Norges Farmaceutiske Forening 1858-1958. Oslo: Norges Farmaceutiske Forening, 1958.

\section{Fortidens mordere}

\section{Sørnes T \\ Ondskap}

De henrettede i Norge 1815-1876. 420 s, ill. Oslo: Schibsted, 2009. Pris NOK 349

ISBN 978-82-516-2720-7

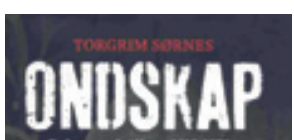

Vi lever dessverre $i$ en tid hvor kriminalitet er blitt noe hverdagslig, og hvor drap ikke er noen sjeldenhet. I 2007 ble 32 personer myrdet i Norge - like mange menn som kvinner (1). Fortidens mordere var nok færre, men hendelsene rundt deres forbrytelser var ofte av mer dramatisk art og ble kjent og levendegjort i datidens samfunn, ofte som gysende underholdning i form av «skil- 